\title{
GREEN COASTAL ZONES: NODES AND CONNECTORS AS STRATEGY OF URBAN REGENERATION
}

\author{
J. TUSET \\ Department of Architectural Design, Valencia Polytechnic University, Spain.
}

\begin{abstract}
The landscape of Valencian Community is a resource with great cultural and heritage value. The system of Green Infrastructure ensures a continuous network of unbuilt areas with high environmental, cultural and visual value that also serves as ecological and functional connectors. The ERAM research project 'Strategies for sustainable regeneration of tourist settlements on the Mediterranean coast' (2012-14) identifies and analyzes the different types of coastal tourist towns of the Valencian region considering their needs for urban regeneration. It proposes strategies for prospective actions that can serve as a model for the regeneration of coastal tourist resorts. The determination of Green Coastal Zones (GCZ) aims to define their potential for urban regeneration in order to establish criteria for regional planning and urban design processes that will foster innovation in mature tourist destinations. The results show the potential of the 11 ERAM areas whose nodal connectivity and multifunctional landscape defines the framework for adaptive design strategies that may present alternative scenarios for touristic settlements. Keywords: landscape architecture, natural resources, touristic impact, touristic planning, touristic potential, touristic regeneration.
\end{abstract}

\section{INTRODUCTION}

The current changes in the economic cycle and the accelerating transformation of the dynamics of the tourism market have led to the establishment of a Global Strategic Tourism Plan (2010-2020) at the Valencian region with the goal of ensuring that tourism stays as one of the economic engines in the upcoming years. This situation implies that it is necessary to restructure mature tourist destinations to make them more sustainable and competitive in order to respond to the new types of touristic demands that are emerging in this sector.

The Tourist Info 2013 survey of the Valencian Tourism Agency [1] indicates that the preferences of the tourists who visited the Valencian region that year, in order of importance, were: resting (29\%), going to the beach (23\%), visiting natural areas (20\%), cultural and local festivals $(16 \%)$, gastronomy (12\%). These activities show that the attractions of this touristic model has enough room for further growth and development.

The Valencian landscape is considered a heritage resource by law. Since 2004, the Valencian politics about landscape define the Green Infrastructure as a system of open spaces and elements of unbuilt spaces of great environmental, cultural and visual value. The evaluation of the territory as a structural support of multiple functions may change the 'sun and beach' model that currently sustains the Valencian tourism sector. This has produced a great amount of banal and decontextualized buildings and tourist areas deprived of character. The implementation of new landscape architecture projects can help to rebuild the image of the place and to offer new services and tourism products that enhance emerging activities (golf, nature, 
health, outdoors etc.). Goula [2] points out this opportunity to improve touristic areas as the construction of a 'second coast'.

As a consequence, to propose strategies for the restructuring of coastal touristic areas of Valencia, a supramunicipal perspective that integrates them into the overall framework defined by a touristic area/destination is required. In order to rejuvenate the tourism model, it is essential to improve and expand tourism services through recreational activities able to foster new dynamics of change, according to Vera and Baños [3], as well as focusing the restructuring with innovative and creative ideas, as suggested by Pie and Vilanova [4]. Any proposal for the renewal of the model must be based on the principles of sustainability and competitiveness of the tourism product. In this sense, the territory and natural elements that structure it can provide strategies to upgrade the model.

The research project 'Strategies for sustainable regeneration of tourist settlements in the Mediterranean coast' (ERAM 2012-2015) has studied the coastal territory of the Valencian region through the identification and analysis of the different types of tourist urban settlements in order to recognize their needs for urban regeneration and to establish strategies for future action. The ERAM project has also made a partial study of coastal touristic areas as potential Green Coastal Zones (GCZ) in order to classify their structural elements and to evaluate the potential of urban regeneration in these areas based only on their natural, environmental and landscape elements. This point of view is based on the concept of sustainable tourism expressed by Sabaté [5], as 'the positive approach that aims to reduce the tensions and conditions created by the complex interactions between the tourism industry, the visitors, the environment and the communities that host tourists'.

The ERAM project continues the subdivision of the Valencian coast established in the Plan de Acción Territorial del Litoral (PATL) (2006), which represents the whole 11 zones in the Valencian coastline. The research was carried out in two distinct phases. The first one involved the identification, analysis and classification of the elements and components of the GCZ. The second phase was the determination of the touristic potential of each ERAM area in order to establish strategies for sustainable regeneration of the coastal tourist settlements.

\section{CHARACTERIZATION OF THE GREEN COASTAL ZONES}

The scope of the study is a coastal strip of 500 meters width within the Valencian coastline. The length of the Valencian coast is 470 kilometers, but there are 60 towns situated in this area, where more than $53 \%$ of the total population live. In addition, $15 \%$ of the regional gross domestic product (GDP) is generated from this area. As a result of the influence of the tourist population, the urban density of the coastal towns reaches the 1,000 inhabitants $/ \mathrm{km}^{2}$ during the vacation months. This area supports a high pressure leading to a strong competition between different land uses.

The first phase of the work consisted in the analysis and study of the GCZ of the Valencian Community by carrying out inventories, drawing tables and making maps. As Corner [6] points out, the scepticism, the criticism and the invention may lead to the creation of new operational fields among the elements studied. For the characterization of the GCZ, two types of spaces were selected: protected natural areas and coastal paths. See Table 1.

Protected natural areas. The elements chosen for this indicator are contained in the Territorial Plan of Green Infrastructure and Landscape of Valencian Community, which establishes the ecological and functional connectors that ensure a continuous network of green areas, that consist of open interconnected spaces (rivers, wetlands, forests, nature parks, etc.), within the central rural areas and coastal towns. According to Steiner [7], Landscape Urbanism is an urban design paradigm and a strategic planning for the post-industrial 
134 Urban Regeneration and Sustainability

Table 1: ERAM areas as GCZ.

\begin{tabular}{|c|c|c|c|c|}
\hline Region & $\begin{array}{l}\text { ERAM } \\
\text { zones }\end{array}$ & Littoral towns & $\begin{array}{l}\text { Natural } \\
\text { areas }\end{array}$ & $\begin{array}{l}\text { Coastal paths } \\
\text { Littoral / inland }\end{array}$ \\
\hline \multirow[t]{4}{*}{ Castellón } & 1 & Vinaròs, Benicarló, Penyiscola & 4 & $1 / 1$ \\
\hline & 2 & $\begin{array}{l}\text { Alcalà de Xivert, Torreblanca, Ca- } \\
\text { banes }\end{array}$ & 4 & $2 / 1$ \\
\hline & 3 & $\begin{array}{l}\text { Orpesa, Benicàssim, Castelló de la } \\
\text { Plana, Almassora, Burriana }\end{array}$ & 4 & $1 / 1$ \\
\hline & 4 & $\begin{array}{l}\text { Nules, Moncofa, Xilches, La Llosa, Al- } \\
\text { menara, Canet d'en Berenguer, Sagunt }\end{array}$ & 4 & $3 / 1$ \\
\hline \multirow[t]{3}{*}{ Valencia } & 5 & $\begin{array}{l}\text { Puçol, Puig, La Pobla de Farnals, } \\
\text { Massamagrell, Massalfassar, Al- } \\
\text { buixech, Albalat dels Sorrells, Foios, } \\
\text { Meliana, Alboraya }\end{array}$ & 1 & $0 / 2$ \\
\hline & 6 & València, Sueca & 1 & $0 / 2$ \\
\hline & 7 & $\begin{array}{l}\text { Cullera, Tavernes de la Valldigna, } \\
\text { Xeraco, Gandia, Daimús, Guardamar } \\
\text { de la Safor, Miramar, Piles, Oliva }\end{array}$ & 8 & $0 / 3$ \\
\hline \multirow[t]{4}{*}{ Alicante } & 8 & $\begin{array}{l}\text { Els Poblets, Dénia, Xàbia, El Poble } \\
\text { Nou de Benitatxell, Teulada, Benissa, } \\
\text { Calp }\end{array}$ & 6 & $3 / 0$ \\
\hline & 9 & $\begin{array}{l}\text { Altea, L'Alfás del Pi, Benidorm, Fines- } \\
\text { trat, La Vila Joiosa }\end{array}$ & 3 & $1 / 1$ \\
\hline & 10 & El Campello, Alacant, Elx, Santa Pola & 2 & $0 / 1$ \\
\hline & 11 & $\begin{array}{l}\text { Guardamar del Segura, Torrevieja, } \\
\text { Orihuela, Pilar de la Horadada }\end{array}$ & 3 & $2 / 1$ \\
\hline
\end{tabular}

Source: PATL (2006).

city that presents different models to address sustainable urban growth. Farra [8] points out that the influence nature has on citizens is well known in a territorial scale (i.e. natural parks, reserves of biodiversity and ecosystem protected areas) but is still unexplored at the urban level. Chiesura [9] proposes that the existence of green spaces in the city leads to an awareness of urban nature, an emotional dimension. Therefore, the system of protected natural areas within a sprawling city requires the integration of natural areas and ecological systems in the production of multiscale urban green spaces that redefine the relationships between the city, nature and the citizen in order to create a system of parks.

Coastal paths. The elements selected for this indicator have been the cattle trails of the coast due to its recent protection by the Valencian law 3/2014 and due to the importance as a secondary network of historical roads. In addition, this system reinforces one of the environmental proposals of the Valencian Territorial Strategy, which is the creation of the Via Litoral. Farina [10] states that hiking is a form of tourism, which is capable of resulting in the exploitation of natural parks and guiding the development of sustainable tourism in rural areas or inland, following the recommendations of the Charter of European Sustainable Tourism. The value of the huge network of cattle trails and historical roads of the Valencian coast enhances 
the development of local tourism: some examples of this in Spain are found in Galicia [11], in the Catalan Pyrenees [12] and Valencia [13]. This model can be implemented on the coast for protecting and conserving the agricultural roads of the littoral towns with the strategic goal of improving the value of the existing historical infrastructure. The use of this secondary network of connectors from different intensities leads to other ways of sustainable mobility and town connectivity.

\subsection{Network landscape}

The creation of maps and cartographies of the GCZ, and its comparison and interaction [14], clearly show two potential actions. These principal factors may guide strategies for the sustainable regeneration of tourist settlements given their consideration as integral parts of the coastal landscape (Fig. 1). These factors are discussed in subsequent text.

Nodes. Protected natural areas offer a wide variety of environments and ecosystems that are reservoirs of biodiversity and areas of great potential for the implementation of a

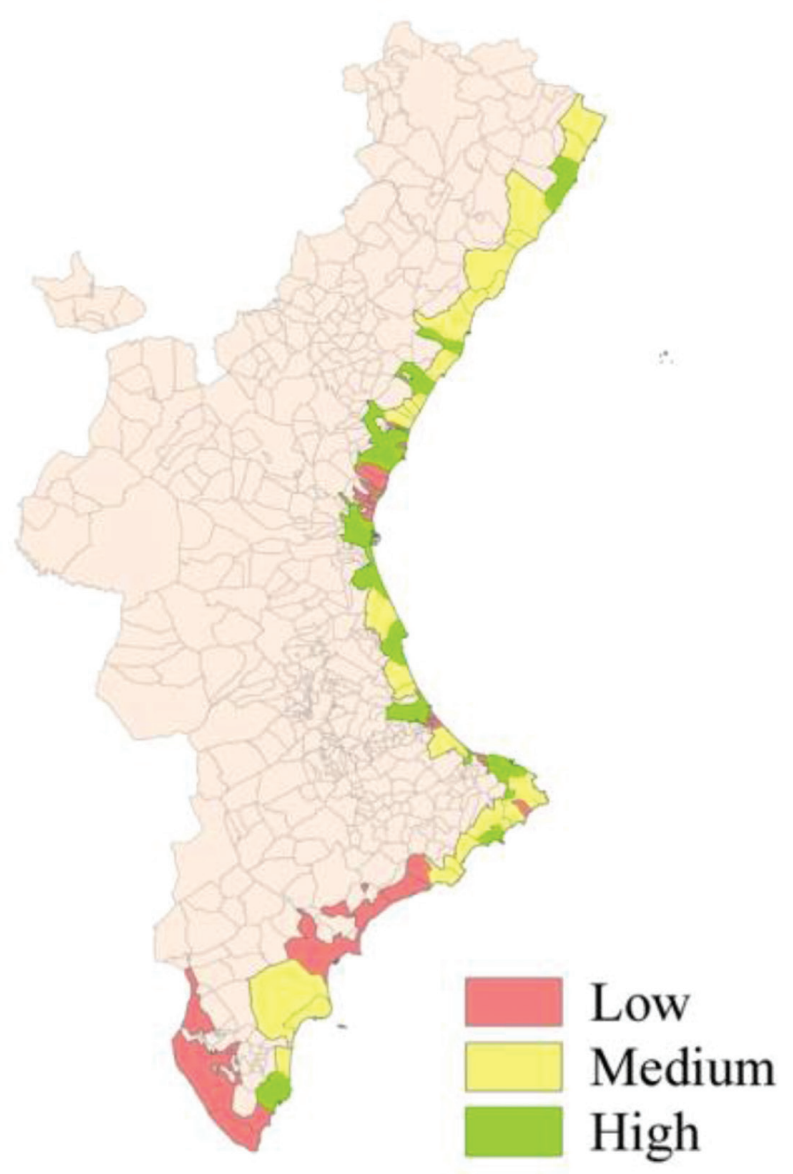

Figure 1: Potential of regeneration: ERAM areas as nodes + connectors. 
sustainable touristic model. In some towns they have an important role, but in other areas they are almost non-existent. The strategic plan may enhance the delimitation of these spaces (protecting the diversity) and procure connectivity among municipalities (defining secondary biological corridors). This will allow achieving two major objectives of the Valencian Territorial Strategy for 2030.

Connectors. Coastal paths, with their cattle trails and historical roads, shape a large communication network that allows a 'human scale' linkage between the urban settlements and other parts of the municipality (interconnection of biodiversities). These paths become connection points along sections throughout the town area that define spaces in the territory that are new centralities - singular nodes - of different scales. An example of this already exists in a lower scale in the various routes and hiking trails of the Valencian Nature Parks.

\section{TOURISTIC POTENTIAL OF THE GCZ}

The second phase of the research was the assessment of the touristic potential of the GCZ of the Valencian Community. This required that an adequate representation of these potentials that characterize the territory from its basic, natural and scenic resources, as well as the structure of the productive system, agricultural, urban and industrial areas was required. In addition, a knowledge was also required of the facilities and infrastructure that allow the contact between different cultures (visitors and locals).

In this research we have followed the model proposed by Leno Cerro [15] and Anton [16], which is based on the analysis of the touristic potential through a method based on three factors: (i) the quantity and the quality of the resources of the studied area; (ii) the accessibility; (iii) the touristic and commercial facilities. Other authors have noted that in addition to these factors, we should consider the existence and permanence of indigenous social communities, which undoubtedly impede the estimation of the touristic potential of a territory, as noted by Rubio [17] and Sancho and Ruiz [18]. In this research, this former aspect was not taken into account.

The real value of the touristic potential of an area cannot be measured only by the numerical quantification of its resources and tourist attractions, infrastructure, accessibility and facilities. It is necessary to assess the quality of each of these factors as well. Consequently, the theoretical formulation of the touristic potential index, or touristic value of an area is estimated as an addition of factors that apply to a different weighting coefficient. In this research, the formula used is as follows:

$$
\mathrm{TPI} i=\alpha \mathrm{RFi}+\beta \mathrm{AFi}+\delta \mathrm{FFi}
$$

Where:

TPI $i=$ tourist potential index of area «i»

$\mathrm{RF}, \mathrm{AF}, \mathrm{FF}=$ resources factors, accessibility factor and facilities factor values.

$\alpha, \beta, \delta=$ weighting coefficients

\subsection{Creation of indicators}

For this work, an inventory of elements has been established to constitute the most decisive factors influencing the potential of GCZ. They are listed in Table 2 and form the basis of any substantial touristic area considered as a Green Coastal Zone. A detailed explanation of the procedure is in Tuset's work [19].

1. Resources: Touristic resources are natural elements or human activities that generate or encourage the journey of tourists. This implies determining the parameters of conservation, 
Table 2: Factors, indicators and elements used to obtain touristic potential.

\begin{tabular}{lll}
\hline Factors & Indicators & Elements \\
\hline & & Nature park \\
& & Wetland \\
Natural & Protected areas & Habitat management area \\
Resources & Managed resource reserve \\
& & Civic nature landscape \\
& & Protected landscape / Seascape \\
& Cattle trails & Woodland \\
Accessibility & & Littoral trail \\
& Artificial touristic & Inland trail \\
Facilities & Beach (Blue flag distinction) \\
& landscapes & Seafront \\
& Marina \\
& & Golf course \\
\hline
\end{tabular}

Source: Territorial Strategy of the Valencian Community (2012).

environmental quality, social value and the current and prospect use of each resource. Given the complexity of such a method, in this research we have selected and used the most representative protected natural areas of the green infrastructure system as the element that better represents a natural resources indicator.

2. Accessibility. In general, this indicator equals the communication and transportation infrastructure. However, in this research we have selected the cattle trails due to their recent protection by Valencian law and the importance of the network of historical paths they shape. These pathways that connect the existing natural areas run along the entire coastline close to the sea and integrate themselves in a soft and continuous road for the transit of both pedestrian and non-motorized vehicles.

3. Facilities. To set up this indicator we have considerably reduced the number of selected elements. The criteria was simple: (a) pick out those that create some of the most important artificial landscapes of the Valencian coast; (b) improve consolidated products as the 'sun and beach' model; (c) promote gastronomic tourism and leisure and (d) create emerging nautical and golf products. The inventory of these items is taken from Volume 10 of the Valencian Territorial Strategy for boosting the tourist model towards sustainable business patterns.

\subsection{Obtaining factors}

\subsubsection{Natural resources}

The assessment of natural resources follows three successive steps: (a) identification of the primary hierarchies; (b) applying a weighting coefficient and (c) calculation of the resource factor. The identification of the primary hierarchies is based on the national, regional or local interest of the resource, taking into account the touristic products that may exist or be proposed as the most important for the development of each area as a whole. This procedure rates the importance of each resource in a scale of 1 to 5. The values are: non-interest (1); local interest (2); regional interest (3) national interest (4) and international interest (5). 


\subsubsection{Accessibility}

This factor has its focus on the internal accessibility to each GCZ. It has been used as a basic element for assessing the road infrastructure composed of historical paths and cattle trails that exist in each coastal town that integrates the studied area. For the determination of accessibility, two types of trails have been considered those that run parallel to the coast have double value than the inland ones. This weighting value aims to positively compensate the areas with roads close to the sea.

\subsubsection{Facilities}

For this factor we have taken into account four types of touristic facilities. First, the beaches (blue flag distinction) have been quantified for being a consolidated touristic product that is growing in number annually and also because its improvement provides high quality to the coastal touristic areas. Secondly, waterfronts have been counted as being specific places that attract urban tourism in the coastal towns and, in particular, support hospitality and leisure activities. Thirdly, the marinas contribute to the consolidation of the emerging product of nautical sports tourism and, in some cases, the old fishing ports turned into modern marinas. Finally, the golf courses have also been taken into account. Despite being very specific touristic products they introduce varied activities like sports and leisure in an artificial landscape.

A more detailed explanation of the formulas and results of the estimation of these three factors are indicated by Tuset [20].

\subsection{Touristic potential index}

Once the values for RF, AF and FF are calculated, the weighting coefficients should be estimated in order to reduce the incidence of randomness. Anton [16] states that 'to minimize the impact of the random factor, we must make assumptions about the value of these coefficients', this means that those elements whose creation did not suffer a direct human impact acquire a higher coefficient because it is considered that if the element does not exist it is very difficult to be created by humans. Accordingly, natural resources always have a higher coefficient than other factors.

The values of the weighting coefficients used have been taken from those proposed by Leno Cerro [15]: $\alpha=1.50, \beta=1.25, \delta=1.00$. Hence, the tourist potential index results are expressed as shown in Table 3.

The TPI values obtained for each ERAM area vary among them with no apparent relationship but to preserve the homogeneity of scales used in the calculation of each factor, the results should be converted to a scale from 0 to 100 based on the area with the highest value obtained. This simple regulatory procedure allows to graphically represent the results of the TPI and states an initial estimation of the touristic potentiality of each ERAM area. See Fig. 2.

\section{RESULTS AND DISCUSSION}

The division of the Valencian littoral space in GCZ allows us to read the territory according to two elements of great potential of regeneration: the protected natural areas and the cattle trails. From these two types of protected spaces we are able to suggest some actions to undertake for sustainable regeneration of coastal tourist settlements.

According to Naveh [21], multifunctional landscapes require adaptive design strategies capable of presenting alternative scenarios. From the results obtained in our research, planning the regeneration of the tourist settlements through the construction of a network of multifunctional landscapes opens the possibility to evaluate, manage and create new types of 
Table 3: Touristic potential factors and index (TPI) results.

\begin{tabular}{llrlrr}
\hline Zone & $\mathbf{R F}$ & AF & FF & TPI & TPI\% \\
\hline $\mathbf{1}$ & 0,90 & 6,33 & 3,1 & 12,36 & 71,01 \\
$\mathbf{2}$ & 2,30 & 6,00 & 3,8 & 14,75 & 84,72 \\
$\mathbf{3}$ & 2,10 & 5,00 & 4,6 & 14,00 & 80,41 \\
$\mathbf{4}$ & 2,00 & 5,33 & 3,6 & 13,26 & 76,18 \\
$\mathbf{5}$ & 0,50 & 10,00 & 1,2 & 14,45 & 83,00 \\
$\mathbf{6}$ & 0,80 & 0,67 & 3,3 & 5,34 & 30,66 \\
$\mathbf{7}$ & 3,00 & 4,33 & 7,5 & 17,41 & 100 \\
$\mathbf{8}$ & 2,30 & 4,67 & 6,7 & 15,99 & 91,83 \\
$\mathbf{9}$ & 1,80 & 2,00 & 6,1 & 11,30 & 64,91 \\
$\mathbf{1 0}$ & 2,30 & 2,00 & 7,4 & 13,35 & 76,68 \\
$\mathbf{1 1}$ & 1,70 & 3,33 & 8,1 & 14,81 & 85,08 \\
\hline
\end{tabular}

RF: resources factor, AF: accessibility factor, FF: facilities factor.

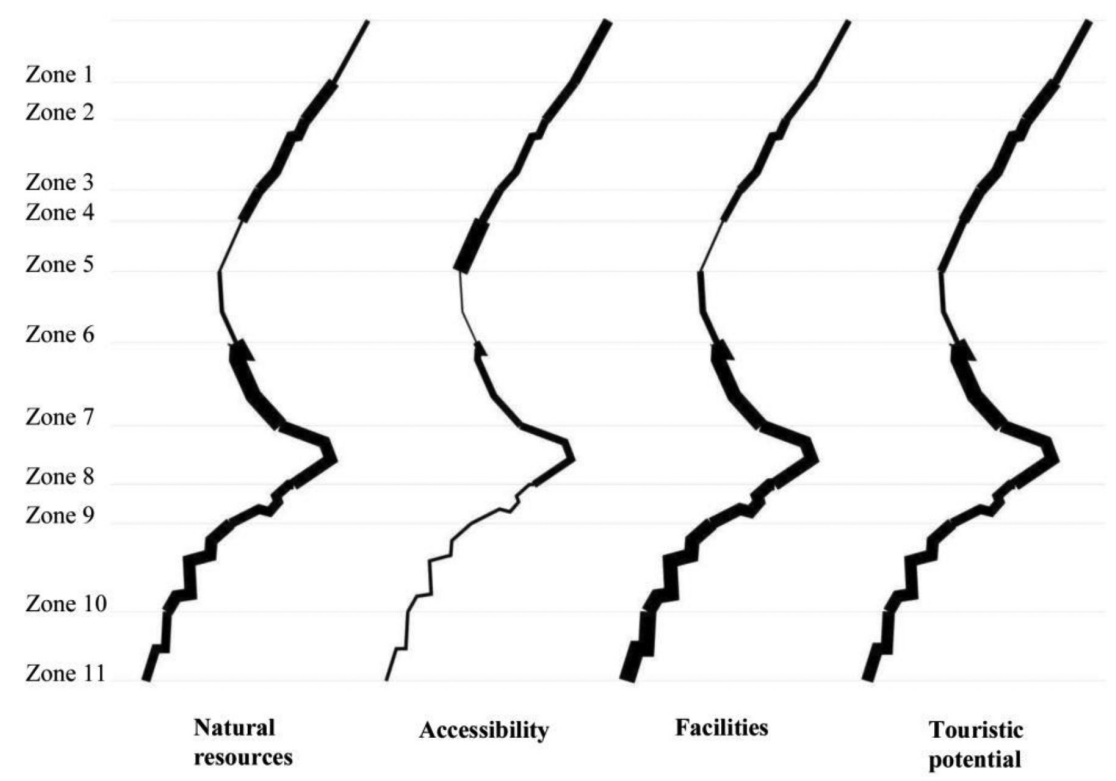

Figure 2: Representation of the touristic potential factors and index (TPI).

landscapes. Generic resources (environmental, cultural and visual), active tourism (business that turns resources into products), human and social production (agriculture and culture) should contribute to a rational use of land in the new tourist landscapes.

The connection of nodes (natural resources) considering the ecology, economy, society and the cultural and social perception of the landscape, contributes to the collaborative work of the urban planner and the architect's strategic vision of the connectivity to plan indicators of sustainable urban regeneration. The renovation of the mature touristic areas of the Valencian coast can hope to achieve their potential when they are considered as GCZ. 
Regarding the touristic potential of coastal areas of the Valencian Community it should be noted that the most important resources are themselves. They are touristic destinations possessing the character of the coastal landscapes. However, the determination of the touristic potentiality of ERAM areas as GCZ evidences some differences between them. The results must be understood from a current as well as a prospective point of view.

ERAM areas of the province of Alicante have a high potential of natural resources, which is indicative of the attraction they present. Areas 2, 3 and 4 (Castellón) have an average value that should stimulate public policies and private investments for their improvement. Areas 7 (Cullera-Oliva) and 8 (Dénia-Calp) have the greatest potential due to the great diversity of natural resources that they contain.

The results obtained from the evaluation of accessibility factors show two clear different situations. The areas that comprise a higher number of coastal trails have a high capacity of connectivity and accessibility between coastal towns and residential areas. By contrast, in the areas where inland paths predominate, there is a major promotion of internal communication between the coastal towns and their inner rural places. In terms of accessibility, both systems, coastal and inland trials, add value to the historical network of roads that form the spinal axis of each GCZ. Thus, each area is able to develop a differentiated and innovative tourist offer.

The data obtained from the facilities factor show that Valencian coastal areas have satisfactory values along the Community. The province of Alicante has a higher potential while Castellón has an average value. The modification of this factor depends mainly on the investment in public and the private businesses. In a collaborative model of tourism entrepreneurship, which follows a proper tourism policy, the offer of existing facilities can be corrected in order to avoid the profound dependence on the 'sun and beach' model.

The touristic potentiality index of the GCZ states that the Valencian coastline is in good health. The density and the centrality of urban settlements along the coast need a connection with the natural resources. This should lead to the development of new strategies for the sustainable regeneration of the tourist settlements, accepting the fact that they are part of a network of nodes and connectors in a multifunctional landscape.

Therefore, these multifunctional landscapes would be considered as a territorial system framed by singular elements that offer the tourists a set of activities in a social community with values and cultures usually different from their own. The combination of all this should continue to contribute to the area's attraction and the motivation of the visit.

\section{REFERENCES}

[1] Tourist info, El Turismo en la Comunitat Valenciana. (Informe anual), INVATTUR Generalitat Valenciana: Valencia, 2013.

[2] Goula, M., Tour-scapes or how to convert mature tourism destinations to complex sustainable landscapes: the strategy of the "second coast". Conference of the International Forum on Urbanism. "6th Conference of the International Forum on Urbanism, IFoU: Barcelona, pp. 1-10, 2012.

[3] Vera, F. \& Baños, C., Renovación y reestructuración de los destinos turísticos consolidados del litoral: las prácticas recreativas en la evolución del espacio turísticos. Boletín de la Asociación de Geógrafos Españoles, 53, pp. 329-353, 2010.

[4] Pie, R. \& Vilanova, J.M., A century of tourism in Europe: new challenges to the discipline of urbanism. Conference of the International Forum on Urbanism. "6th Conference of the International Forum on Urbanism. IFoU: Barcelona, pp. 1-6, 2012. 
[5] Sabaté, J., Turisme sostenible: experiències europees aplicables a Catalunya. Barcelona: Consell Assessor per al Desenvolupament Sostenible i Departament d'Innovació, Universitats i Empresa. Generalitat de Catalunya, pp. 11-13, 2007.

[6] Corner, J., The agency of mapping: speculation, critique and invention, Mapping, ed. D. Cosgrove, Nueva York: Reaktion Books, 1999.

[7] Steiner, F., Landscape ecological urbanism: origins and trajectories. Landscape and Urban Planning, 100, pp. 333-337, 2011.

http://dx.doi.org/10.1016/j.landurbplan.2011.01.020

[8] Farra, F., Parque natural y turismo de masas: ¿compatibilidad? Investigaciones Geográficas, 29, pp. 39-56, 2002. http://dx.doi.org/10.14198/INGEO2002.29.02

[9] Chiesura, A., The role of urban parks for the sustainable city. Landscape and Urban Planning, 68, pp. 129-118, 2004. http://dx.doi.org/10.1016/j.landurbplan.2003.08.003

[10] Fariña, J., Turismo y uso sostenible del territorio: El senderismo como posibilidad para los pequeños municipios. Cuadernos de Investigación Urbanística, 28. Madrid: Sección de Urbanismo del Instituto Juan de Herrera (SPyOT), Escuela Técnica Superior de Arquitectura de Madrid, pp. 65-72, 1999.

[11] Nárdiz, C., La planificación de una red de sendas para el recorrido del litoral de la provincia de A Coruña. Revista de Obras Publicas, 3494, pp. 23-40, 2008.

[12] Guardia, C., La creación de una red de senderos locales como estrategia turística de futuro en zonas de montaña: el caso de Alp. XII Coloquio de Geografía del Turismo, Ocio y Recreación, ed. S. Fernández, Universidad Carlos III: Madrid, pp. 43-51, 2011.

[13] Diez, D., La diversificación turística como estrategia clave para la reactivación de destinos consolidados del litoral: la reinvención de Cullera (España). Actas Seminario Internacional Renovación y Restructuración de destinos turísticos consolidados del litoral, Univesitat d'Alacant: Alicante, pp. 53-63, 2011.

[14] Tapiero, M. \& Tuset, J., Espacios verdes litorales: estrategias de regeneración de los asentamientos turísticos en la costa mediterránea. Actas Proceeding 4th European Conference on Energy Efficiency and Sustainability in Architecture and Planning, ed. R. Hernández, UPV: San Sebastián, pp. 11-20, 2013.

[15] Leno Cerro, F., Técnicas de evaluación del potencial turístico, Madrid: Secretaría General de Turismo-Turespaña, 1993.

[16] Antón, S., Planificación territorial del turismo, UOC: Barcelona, 2005.

[17] Rubio, A. (ed), Sociología del turismo, Ariel: Barcelona, 2003

[18] Sancho, A. \& Ruiz, P., Planteamiento metodológico para el uso de indicadores en la gestión turística de Espacios Naturales Protegidos. IX Congreso AECIT. El uso turístico de los espacios naturales, pp. 34-47, 2004.

[19] Tuset, J., Paisajes en red. (chapter 6) Orilla marítima. Territorio litoral, eds. J. Tuset \& R. Temes, Ediciones Generales de la Edificación: Valencia, 2015.

[20] Tuset, J., Tapiero, M \& Mas, V., Conectividad nodal: potencial turístico de la costa valenciana. Proceeding Seminario Internacional "Innovación y competitividad en Áreas Turísticas (ICAT2014) eds. J.F. Vera et al. Instituto Universitario de Investigaciones Turísticas (UA): Alicante, pp. 122-137, 2014.

[21] Naveh, Z., Ten major premises for a holistic conception of multifunctional landscapes. Landscapes and Urban Planning, 57, pp. 269-284, 2001.

http://dx.doi.org/10.1016/S0169-2046(01)00209-2 